\title{
Current status of Peruvian Terns Sternula lorata in Perú: threats, conservation and research priorities
}

\author{
CARLOS B. ZAVALAGA, JESSICA HARDESTY, GINA P. MORI, \\ CÉSAR CHÁVEZ-VILLAVICENCIO and ALEJANDRO TELLO
}

\begin{abstract}
Summary
Peruvian Terns Sternula lorata breed in the sand desert plains of the coast of Perú and northern Chile. Because of their long-term population decline, Peruvian Tern is categorized as 'Endangered' on the IUCN Red List. The observations that formed the basis for that decision were made in the 1970s and 1990s. In this study, we compile information on distribution, numbers, habitat use and threats of Peruvian Terns that has become available between 2003 and 2008 from 14 localities on the Peruvian coast. Peruvian Tern sites are located between the mangroves of San Pedro de Vice in the north $\left(5^{\circ} 31^{\prime} S\right)$ and the wetlands of Ite in the south $\left(17^{\circ} 56^{\prime} \mathrm{S}\right)$. From the 14 locations, five are reported for first time: Virrilá, Eten, Huanchaco, isla Mazorca and Ite. There were only four active breeding sites: Pacasmayo, Paraíso, Pampa Lechuzas and Tres Hermanas-Yanyarina; however, some localities were visited outside the breeding season and should be surveyed between October and February to search for nests. The presence of 283 individuals was confirmed at the 14 sites in an area of approximately 1,388 ha (which represents only $0.35 \%$ of the total suitable area for nesting along the Peruvian coast). Thus, the number of Peruvian Terns in Perú should increase with systematic surveys. Here for the first time we report the importance of wetlands for the Peruvian Terns ( $43 \%$ of the sightings occurred in this habitat). Wetlands can offer optimal conditions for feeding, but the cost of using them is becoming higher with a sharp increase of human expansion into coastal areas and urban development around wetlands. We identified the following threats affecting Peruvian Terns on their feeding and breeding grounds: 1) recreational activities; 2) off-road driving by fishermen and tourists; 3) wetland pollution and water use for irrigation; 4) conversion of desert plains to agricultural land; 5) management of wetland water levels; 6) presence of feral cats and dogs, and 7) oil exploration on the desert plains. These adverse factors can be eradicated by the protection of tern sites and public awareness and education. Conservation actions, monitoring and research priorities are suggested.
\end{abstract}

\section{Resumen}

Los Gaviotines Peruanos Sternula lorata se reproducen en las planicies arenosas del desierto de las costas del Perú y norte de Chile. Debido a la disminución de su población, los Gaviotines Peruanos están categorizados como 'En Peligro' por la Lista Roja de la UICN. Las observaciones que formaron la base para esa decisión fueron realizadas en los años 7os y gos. En este estudio se presenta información de distribución, número, uso de hábitat y amenazas de los Gaviotines Peruanos que ha sido disponible entre el 2003 y el 2008 en 14 localidades de la costa peruana. Los sitios en que se encontraron Gaviotines Peruanos están localizados entre los manglares de San Pedro de Vice en el norte $\left(5^{\circ} 31^{\prime} S\right)$ y los humedales de Ite en el sur $\left(17^{\circ} 56^{\prime} S\right)$. De las 14 localidades 
visitadas, en cinco se vieron por primera vez Gaviotines Peruanos: Virrilá, Eten, Huanchaco, isla Mazorca e Ite. Se identificaron solamente cuatro sitios de reproducción en el Perú durante el período de estudio: Pacasmayo, Paraíso, Pampa Lechuzas y Yanyarina; sin embargo, algunas localidades fueron visitadas fuera de la estación reproductiva y deberían ser inspeccionadas entre Octubre y Febrero en busca de nidos. La presencia de 283 individuos fue confirmada en las 14 localidades, en un área aproximada de 1,388 ha (lo cual representa solamente el o.35\% del área total que podría ser utilizada por los gaviotines). Así, el número de Gaviotines Peruanos en el Perú debería de incrementarse con censos sistemáticos. Reportamos por primera vez la importancia de los humedales para los Gaviotines Peruanos (43\% de los avistamientos ocurrieron en este hábitat). Los humedales pueden ofrecer condiciones óptimas para la alimentación, pero el costo de usarlos podría ser alto debido al rápido incremento de la población humana en zonas costeras y al desarrollo urbano alrededor de los humedales. Identificamos las siguientes amenazas que afectan a los Gaviotines Peruanos en sus zonas de reproducción y alimentación: 1) actividades recreacionales; 2) manejo fuera de trochas en el desierto de automóviles de pescadores y turistas; 3) contaminación de los humedales y uso de sus aguas para irrigación de cultivos; 4) transformación del desierto en tierra agrícola; 5) manejo en los niveles de agua de los humedales; 6) presencia de gatos y perros, y 7) exploración petrolera en las planicies costeras del norte. Estos factores adversos podrían ser erradicados protegiendo los sitios que utilizan los gaviotines, y educando al público de la importancia que tienen estos sitios. Se sugieren acciones de conservación, monitoreos y prioridades de investigación.

\section{Introduction}

The Peruvian Tern Sternula lorata breeds on the coast of Perú and northern Chile (Murphy 1936, Goodall et al. 1951). By the beginning of the last century, Peruvian Terns were known from eight localities (only Pacasmayo was confirmed as a breeding site; see Figure $I$ for all locations mentioned in the text) along the coast and islands of central-northern Perú, with exceptional records of tens of thousands of non-breeding birds in the port of Paita (Murphy 1936). In the 1970s, four new breeding colonies at Puerto Viejo (Zavalaga et al. 2008), Mollendo (Hughes 1970), Tres Hermanas-Yanyarina (Galarza 1968) and Pativilca (Zavalaga et al. 2008) were added to the list of Peruvian Tern localities. Between 1995 and 2006, the presence of Peruvian Terns in Perú was associated with only one non-breeding site: San Pedro de Vice (Chávez 2007, Valega 2007), and three breeding localities: Paraíso (Tello et al. 2005), Pampa Lechuzas and Tres Hermanas-Yanyarina (Zavalaga et al. in press). Thus, eight non-breeding and seven breeding localities were documented in Perú before 2007. Current numbers of Peruvian Terns are unknown because Perú's 2,500-km desert coast has never been completely surveyed. A similar situation has been observed along the northern Chilean coast, where Peruvian Tern breeding sites have been documented in Arica (Devillers and Terschuren 1976), IquiqueChucumata (Goodall et al. 1951), Río Loa delta (Guerra-Correa 2003) and in the Peninsula of Mejillones from Chacaya to La Rinconada (Vilina 1998, González 1990, Rottmann and González 1991). In the Mejillones area, a total of $257-287$ individuals distributed at eight colonies have been recently counted (Guerra-Correa 2003). However, these estimates represent minimum numbers as a large proportion of the northern Chilean desert plains have remained unexplored. Likewise, at all Chilean locations, Peruvian Terns were exclusively associated with inland desert plains ( $1-2 \mathrm{~km}$ from the coastline), probably to avoid encounters with terrestrial predators (Vilina 1998, Guerra-Correa 2003). Nevertheless, some locations on the Peruvian coast are on sandy beaches associated with coastal wetlands (Zavalaga et al. 2008). The importance of this habitat as nesting and feeding grounds for Peruvian Terns has remained unknown.

Although well suited for living in the arid environment of the desert, Peruvian Terns are facing new threats as a consequence of human development and expansion into coastal areas, especially in recent decades. In Perú, human population grows at a steady annual rate of $1.6 \%$ (INEI 2008). Population growth and immigration into coastal areas, where most of the major cities are located, 


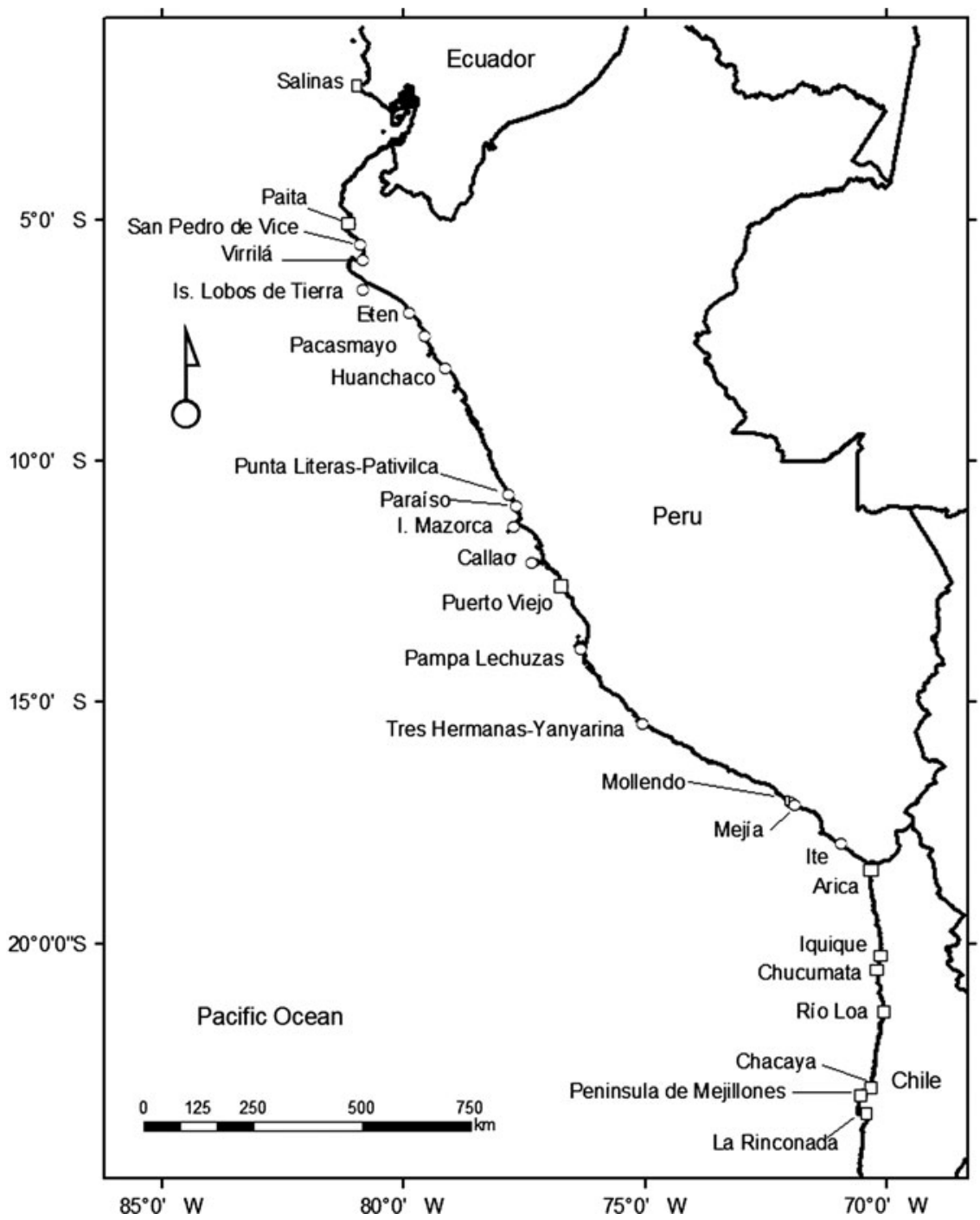

Figure 1. Locations of Peruvian Tern, Sternula lorata, sites along its distribution range. The 14 locations surveyed in this study are shown in open circles, whereas other Peruvian Tern locations mentioned in the text are shown in open squares.

resulted in an increase in the coastal human population from 7.7 million to 15 million between 1970 and 2007 (INEI 2008). In the early 1920s, Peruvian Terns were still abundant and common in some localities of the Peruvian coast (Coker 1919, Murphy 1936), but human activities in recent years have forced them to abandon wintering and breeding locations used in the past (e.g. Puerto Viejo, Mollendo; Zavalaga et al. 2008). Disturbance, displacement, habitat destruction and presence of introduced terrestrial predators (e.g. dogs, cats, rats) in their breeding sites are some of the main threats that place this species at risk of extinction. Because of its small population size and patchy distribution, the Peruvian Tern has been recognized as 'Endangered' (Birdlife International 2008) and as 'Vulnerable' in Perú (Decreto Supremo No O34- $^{-}$ 2004-AG, www.inrena.gob.pe). Current information on the distribution and habitat use of the 
species is urgently needed to highlight research priorities and design effective plans for their conservation.

In this paper we use our observations and unpublished records of tern sightings collected between 2003 and 2008 to describe the current patterns of distribution, identify new nesting areas and evaluate current human-related threats of Peruvian Terns in Perú. Based on this information, we advise conservation actions and research priorities.

\section{Methods}

\section{Species account}

Peruvian Terns are one of the smallest terns with a total length of $23 \mathrm{~cm}$ (Harrison 1985) and chicks' asymptotic body weight of $50 \mathrm{~g}$ (Guerra-Correa 2003, Zavalaga et al. in press). They nest over large, open areas on the mainland desert plains (Murphy 1936, Vilina 1998). One of the most noteworthy traits of Peruvian Terns is their lack of gregariousness. Breeding sites typically have fewer than 10 nests, with densities of $5^{-7}$ nests $\mathrm{km}^{-2}$ (Vilina 1998, Zavalaga et al. in press). Breeding is asynchronous with egg-laying from September-October to January-February (Vilina 1998, Guerra-Correa 2003, Zavalaga et al. in press). Post-breeding dispersal to unknown areas occurs between March-April and August-September (Zavalaga et al. in press). Peruvian Terns lay one or two eggs, which are well-camouflaged on the bare ground, but usually only one chick fledges (Guerra-Correa 2003). Chicks are very mobile within a few days of hatching and are fed predominantly with small pelagic fish. The main predators include foxes Pseudalopex spp. and gulls Larus spp.

\section{Sightings and counts}

Between October 2003 and February 2008, we compiled information on numbers of Peruvian Terns at 14 localities on the coast of Perú, which included nesting areas, non-breeding sites and at sea. We did not survey the $2,500-\mathrm{km}$ of Peruvian coast and therefore the numbers reported are minimum values of population size and must be treated with caution because a large proportion of potential habitat for terns was unexplored (see results). The sources of information can be divided into two categories: (i) direct counts of active nests and individuals made by the authors and (ii) opportunistic sightings of terns (at non-breeding areas and at sea) undertaken by professional birdwatchers on pelagic tours and seabird biologists. The latter observations were reported to the corresponding author as personal communications and considered reliable. At the breeding sites, the first nest was usually found by chance or by following flying terns that landed close to their nests. Once the first nest was located, one or two researchers walked transects in all directions around the nest during 4-6 hours to locate as many nests, chicks and adults as possible. The areas surveyed varied among localities from two to 1,200 ha, and all individuals (adults and juveniles) present during our visits were counted with the aid of binoculars. Distances and areas were estimated by visualization in Google Earth ${ }^{\mathrm{TM}}$. Only nests with eggs and chicks were considered active. In non-breeding sites and at sea, terns were followed for short periods of time and identified with the aid of binoculars at distances $<50 \mathrm{~m}$. In some localities, we took notes on the habitat, presence of predators and disturbance associated with human activities. We also report population trends at sites where the terns were counted for several years during the course of other fieldwork (Paraíso, San Pedro de Vice).

\section{Results}

The small proportion of area surveyed (in comparison to the total suitable area for terns), as well as the wide variability in survey dates and search effort precludes any reliable estimates of the 
population size. A list of the coordinates of the study sites, habitat, survey dates, numbers and data source is shown in Table 1 .

\section{Distribution}

Peruvian Terns were found between the mangroves of San Pedro de Vice in the north and the wetlands of Ite in the south (Table I; Figure 1). Nesting was confirmed in only four localities during the study period: Pacasmayo, Paraíso, Pampa Lechuzas and Tres Hermanas-Yanyarina. San Pedro de Vice, Punta Literas-Pativilca and Ite were visited during the breeding season, but no nests were found, whereas other sites were surveyed during the non-breeding period and need additional surveys for breeding confirmation. The number of nests detected at each breeding locality was small (3-7 nests; Table 1). Terns were associated either with wetlands ( $43 \%$ of the total number of localities, Table 1 ), inland desert plains $(<2 \mathrm{~km}$ from the coastline, $36 \%$ ) or the open ocean up to $45 \mathrm{~km}$ offshore (21\%). The number of terns sighted both at sea and on the mainland or islands was generally small (4-32 individuals), except on Isla Lobos de Tierra where c. 100 birds were recorded on one occasion (Table 1 ).

\section{Breeding sites}

Pacasmayo: The terns were found on a plateau of $c .200$ ha and located $2.5 \mathrm{~km}$ southwest of the port of Pacasmayo. Although 56 ha of the plateau were inspected, we found adults and three nests with chicks within an area of 2 ha in mid-January 2008. These nests were located 400-450 $\mathrm{m}$ from the shoreline and contained two new hatchlings, two medium-size chicks, and one large chick, respectively. The substrate was a reddish sand covered with small stones and broken shells. There was no vegetation. The plateau was crossed by 3-4 firm sand roads used daily by 3-wheel taxis to transport local seaweed extractors and their dogs to the beach. One of these roads bisected the tern's nesting area (one nest was located $30 \mathrm{~m}$ away from the road). Pacasmayo was the first breeding site reported for the Peruvian Terns in 1920 (Murphy 1936).

Paraíso: Terns occupied a narrow sand beach $(0.2 \times 3 \mathrm{~km}, 6 \mathrm{o} \mathrm{ha})$ running parallel to the coastal lagoon of Paraíso. This shallow wetland is located ıo km south of the city of Huacho. Bi-monthly counts revealed that the numbers of terns varied from 14 birds (adults and juveniles) in October 2003 to zero in February 2008. Peruvian Terns were seen regularly up to July 2007 and then no more sightings were reported until March 2008 when three individuals were present on the beach. There was no clear seasonal pattern in the number of terns, but the highest counts during a year were usually recorded in July and October. Breeding was only recorded in OctoberNovember 2003, with a maximum of three nests containing four medium-sized chicks and one small chick within an area of approximately 1 ha. Nests were located 100-150 $\mathrm{m}$ from the high tide mark. During the summer, the beach is visited by local people and dogs, whereas during the winter the area is frequently crossed by ${ }_{4} \mathrm{WD}$ vehicles and fishermen. Human presence and disturbance in the terns' nesting area have considerably intensified since 2003.

Pampa Lechuzas: This is a desert plateau with a firm sand, gravel and salt crust substrate, which prevents plant growth. The plain has an area of approximately 600 ha, but terns and their nests occupied only $c .7$ ha, located $1.5 \mathrm{~km}$ inland from the fishing village of Lagunillas, Peninsula de Paracas. We were unable to survey the entire area, but observed a nest with eggs, and many adults in a brief visit in January 2008. This site is within the boundaries of the Paracas National Reserve. First active nests were discovered in 1995 (Zavalaga et al. 2008), but this site has been apparently used by the terns at least since 1919 (Murphy 1936).

Tres Hermanas-Yanyarina: This desert plateau, with an area of $c .1$,ooo ha, is located $16 \mathrm{~km}$ south of the town of Marcona. Breeding in this site has been described in the late 196os by Galarza (1968) and in the late 1990s by Zavalaga et al. (2008). In January 2008, two nests and one chick were observed in an area of $c .3$ ha located $>0.5 \mathrm{~km}$ inland. At least 32 volant 
Table 1. Locations and numbers of Peruvian Tern, Sternula lorata, at the 14 surveyed areas along the coast of Perú between 2003 and 2008.

\begin{tabular}{|c|c|c|c|c|c|c|}
\hline Locality & Coordinates & Habitat & Observation period & Max No. nests & Max. No. birds. & Source \\
\hline \multicolumn{7}{|l|}{ Breeding sites } \\
\hline Pacasmayo & $7^{\circ} 24^{\prime} \mathrm{S}, 79^{\circ} 35^{\prime} \mathrm{W}$ & Desert Plain & $12-13$ Jan 2008 & 3 & 7 & C. Zavalaga, G. Mori \\
\hline Paraíso & $11^{\circ} 11^{\prime} \mathrm{S}, 77^{\circ} 35^{\prime} \mathrm{W}$ & Wetland & $\begin{array}{l}\text { Bimonthly from Oct } 2003 \\
\text { to Feb } 2008\end{array}$ & 3 & 14 & A. Tello \\
\hline Pampa Lechuzas & $13^{\circ} 53^{\prime} \mathrm{S}, 76^{\circ} 20^{\prime} \mathrm{W}$ & Desert plain & 24 Jan 2008 & $7^{*}$ & 15 & J. Hardesty \\
\hline $\begin{array}{l}\text { Tres Hermanas-Yanyarina } \\
\text { Non-breeding sites }\end{array}$ & $15^{\circ} 27^{\prime} \mathrm{S}, 75^{\circ} \mathrm{O} 3^{\prime} \mathrm{W}$ & Desert plain & 26 Jan 2008 & 3 & 32 & J. Hardesty \\
\hline San Pedro deVice & $5^{\circ} 31^{\prime} \mathrm{S}, 80^{\circ} 53^{\prime} \mathrm{W}$ & Wetland & $\begin{array}{l}\text { Jul 2004-2007 } \\
9-11 \text { Jan } 2008\end{array}$ & & 31 & $\begin{array}{l}\text { C. Chávez } \\
\text { C. Zavalaga, G. Mori }\end{array}$ \\
\hline Virrilá & $5^{\circ} 50^{\prime} \mathrm{S}, 80^{\circ} 5 \mathrm{I}^{\prime} \mathrm{W}$ & Wetland & Jul 2007 & & 4 & C. Chávez \\
\hline Isla Lobos de Tierra & $6^{\circ} 26^{\prime} \mathrm{S}, 80^{\circ} 5^{1^{\prime} \mathrm{W}}$ & Desert plain & Jun 2006 & & 100 & A. García-Godos, per. comm. \\
\hline Eten & $6^{\circ} 55^{\prime} \mathrm{S}, 79^{\circ} 54^{\prime} \mathrm{W}$ & Wetland & 28 Oct 2006 & & 15 & F. Angulo, per. comm, \\
\hline Huanchaco & $8^{\circ} \mathrm{O}^{\prime} \mathrm{S}, 79^{\circ} \mathrm{O} 7^{\prime} \mathrm{W}$ & Sea & II Aug 2007 & & 7 & C. Zavalaga \\
\hline Punta Literas-Pativilca & $10^{\circ} 35^{\prime} \mathrm{S}, 77^{\circ} 53^{\prime} \mathrm{W}$ & Desert Plain & 23 Jan 2008 & & 13 & C. Zavalaga, G. Mori, J. Hardesty \\
\hline Isla Mazorca & $11^{\circ} 22^{\prime} \mathrm{S}, 77^{\circ} 43^{\prime} \mathrm{W}$ & Sea & 4 Dec 2007 & & 4 & C. Zavalaga \\
\hline$<40 \mathrm{~km}$ offshore Callao & $12^{\circ} \mathrm{O} 5^{\prime} \mathrm{S}, 77^{\circ} 19^{\prime} \mathrm{W}$ & Sea & $\begin{array}{r}\text { Monthly pelagic trips } \\
\text { between } 2003-2007\end{array}$ & & 10 & G. Engblom, pers. comm. \\
\hline Mejía & $17^{\circ} \mathrm{O} 2^{\prime} \mathrm{S}, 72^{\circ} \mathrm{OO}{ }^{\prime} \mathrm{W}$ & Wetland & 2004 & & 1 & M. Ugarte-Lewis, pers. comm. \\
\hline Ite & $17^{\circ} 56^{\prime} \mathrm{S}, 70^{\circ} 56^{\prime} \mathrm{W}$ & Wetland & $\begin{array}{l}\text { 14 Jul } 2007 \\
15 \text { Jan } 2008\end{array}$ & & 30 & $\begin{array}{l}\text { C. Zavalaga } \\
\text { C. Zavalaga, G. Mori }\end{array}$ \\
\hline
\end{tabular}

${ }^{*}$ Maximum number of nests recorded in December 1996 because no search for nest was done in 2008 (Zavalaga et al. 2008) 
individuals were present, though they seemed to be young of the year. Two birds were observed in aerial display with small fish. The sandy terrain is devoid of vegetation and covered with small pieces of broken shells and small stones. The plain is crisscrossed by several firm sand roads used daily by divers, seaweed extractors and inter-tidal shellfish collectors. Some fishermen camps with dogs were present in nearby areas, and dog tracks were common around tern nests.

The total area surveyed in these four breeding sites (Pacasmayo $=56$ ha, Paraíso $=60$ ha, Pampa Lechuzas $=7$ ha, Tres Hermanas-Yanyarina $=3$ ha) was 126 ha.

\section{Non-breeding sites}

San Pedro de Vice: This is the southernmost mangrove on the Pacific coast with a total area of $c$. 1,200 ha. Terns were observed resting or feeding on the sandy shores and shallow waters at the northern limit of the main channel (where it opens to the sea). Yearly counts showed that the number of terns increased from six in February 1999 to 31 individuals in July 2006, when six juveniles were seen for the first time. After 12 hours searching the desert plains and beaches surrounding the mangrove, we were unable to confirm breeding activities in January 2008. Large groups of fishermen and visitors frequently use the northern end of the mangrove for invertebrate harvesting and recreation, especially during the summer. Oil exploration by a private corporation in areas around the mangroves has been recently authorized by the Peruvian government. These activities will cause the destruction of possible nesting sites for Peruvian Terns and irreversible damages to the mangrove ecosystem.

Virrilá: This is a narrow, long and winding saltwater estuary located $25 \mathrm{~km}$ south of the town of Sechura. Terns were seen flying along the estuary $4 \mathrm{~km}$ east of the sea shore in July 2007.

Isla Lobos de Tierra: This island lies $12-20 \mathrm{~km}$ from the mainland and is the largest guano island along the Peruvian coast (area of $c .1,420$ ha). Unlike most of the Peruvian islands, Lobos de Tierra offers several flat areas and sandy beaches suitable for terns. A group of approximately 100 terns were resting on a plain $1-1.5 \mathrm{~km}$ northwest of the guard houses on June 2006. The island is inhabited by a large number of feral cats, which may deter tern settlement and breeding.

Eten: Terns were feeding and courting in a small coastal wetland located $1-2 \mathrm{~km}$ north of the port of Eten, northern Perú. Breeding has not been confirmed in the area around the wetland, but terns were frequently seen at nearby desert plains and beaches in October 2006.

Huanchaco: This very popular beach is in the city of Trujillo. Some terns were flying southward along the shoreline while others were feeding $<100 \mathrm{~m}$ in front of the pier. In an hour of observation, a total of seven terns was counted in August 2007.

Punta Literas-Pativilca: This place is located $100 \mathrm{~m}$ south of the abandoned guano-bird headland of Punta Literas. We found 13 terns flying and landing over a sand plateau of approximately 75 ha. We searched for nests $200 \mathrm{~m}$ from the shore, in an area of approximately 2 ha where the terns usually landed, but no chicks or eggs were found in two hours of search. Terns frequently flew over the area for several minutes chasing each other in aerial displays. The shores are regularly visited by local shellfish extractors and in the tern area there were several abandoned chicken farms. Approximately $0.5 \mathrm{~km}$ south of the tern area, we noted the presence of several water pipes used to irrigate the sandy substrate for agricultural purposes. Compared to other sites, the degree of human disturbance was low.

Isla Mazorca: This island lies $25 \mathrm{~km}$ southwest of the city of Huacho. Terns were feeding on waters around three small islets located 1-2 km southeast of Isla Mazorca in December 2007.

Offshore of Callao: Eleven sightings at sea between January 2000 and November 2007 were reported by professional birdwatchers (www.birding-peru.com) during pelagic trips $<40 \mathrm{~km}$ offshore the port of Callao. Terns were either traveling or feeding.

Mejía: This coastal wetland is a legally protected sanctuary that stretches parallel to the coastline for nearly $7 \mathrm{~km}$. Only one tern was sighted flying along the shoreline in 2004, approximately $15 \mathrm{~km}$ south of the abandoned Peruvian Tern breeding site of Mollendo (Hughes 1970). 
Ite: This is a coastal wetland artificially generated by transplanting local flora over oxidizing porphyric copper tailings deposited between 1960 and 1997 at the Bahía de Ite. A flock of 30 Peruvian Terns was seen in July 2007 at the southern end of a $12 \mathrm{~km}$ long and $50 \mathrm{~m}$ wide sandy beach that divides the ocean from the lagoons and marshes (the entire beach was walked in search for terns). This beach is regularly crossed by $4 \times 4$ vehicles that are used to pull fishing nets ashore. We also observed four small fishing camps. We returned in January 2008 in search for nests, but the construction of a $1.5-\mathrm{m}$ high sand dam was in progress to raise the lagoon water level. This dam ran parallel to the wetland shores, stretched approximately $2 \mathrm{~km}$ northward and crossed the area used by the terns on our previous visit. In our last visit, Peruvian Terns were not sighted on the beach or in the desert plains east of the southern end of the wetland.

The total area surveyed in San Pedro de Vice ( 1,200 ha), Punta Literas ( 2 ha) and Ite (6o ha) was 1,262 ha. The area of the remaining locations was not estimated because the sightings occurred either at sea or at small spots on the mainland. Thus, by adding the areas of breeding and nonbreeding locations, the total area surveyed during this study was 1,388 ha. The Peruvian coast stretches for nearly 2,500 km, of which $1,950 \mathrm{~km}$ are classified as beaches and inland flat plains (Zavalaga et al. 2002). Peruvian Terns have usually been found $<2 \mathrm{~km}$ inland (Murphy 1936, Vilina 1998, Zavalaga et al. 2008), and therefore a maximum suitable area for terns may cover $1,950 \mathrm{~km}$ along the coast in a band of $2 \mathrm{~km}$ wide (390,000 ha). Thus, the total number of 283 Peruvian Terns reported in this study (Table I) was counted in an area equivalent to $0.35 \%$ of the total potential nesting area.

\section{Discussion}

Five main patterns emerged from our sightings of Peruvian Terns: 1) there are more tern locations than previously reported; 2 ) new tern sites were discovered as a result of a higher search effort; 3) the number of individuals was generally small at each locality; 4) coastal wetlands are important habitats for foraging and reproduction; and 5) terns adversely interact with humans in some localities (e.g. San Pedro de Vice, Paraíso, Ite).

\section{Distribution}

This study reports the presence of Peruvian Terns at 14 sites, five of which have not been previously reported (Virrilá, Eten, Huanchaco, Isla Mazorca and Ite). There are only four known active breeding colonies: Pacasmayo, Paraíso, Pampa Lechuzas and Tres Hermanas-Yanyarina. The increase in the number of localities, in comparison to previous years, is likely the result of growing scientific interest, consciousness of coastal wetland management and protection, and enthusiastic birdwatching activities. We expect that directed surveys and thorough searches in the Peruvian desert may add new nesting and wintering sites in the future.

Based on our observations, the current distributional range of Peruvian Terns in Perú stretches c. 2,200 km from the mangroves of San Pedro de Vice southward to the wetlands of Ite (Figure 1 ). Reports of vagrants indicate that terns can disperse northward up to Salinas, a few kilometres north of the Gulf of Guayaquil, Ecuador (B. Haase pers. comm.). Although the southern limit for the occurrence of Peruvian Terns is the breeding locality of La Rinconada, a few kilometres south of the Peninsula of Mejillones, Chile (Rottmann and González 1991), movements further south are less clear.

\section{Numbers}

In spite of the discovery of new locations and the identification of nesting areas for Peruvian Terns, the number of birds sighted at each locality was usually small ( $<35$ individuals) as was the number of nests found at the breeding sites (maximum of seven nests). It is likely that these 
numbers are the result of low search effort, breeding asynchrony, and the difficulty of detecting nests in the featureless environment of the desert. However, previous reports of nesting sites, including those that have been regularly monitored, reveal that colonies have always been small, only 5-30 nests in Perú (Murphy 1936, Zavalaga et al. 2008) and 5-50 nests in Chile (GuerraCorrea 2003, Vilina 1998). Therefore, even with a higher search effort, we would not expect a large increase in the total number of nests at each site, certainly no more than a ten-fold increase. We counted a total of 283 Peruvian Terns in approximately $0.35 \%$ of the total area of the Peruvian desert that may be potentially used for nesting. Although it may be inappropriate to make extrapolations to the total Peruvian coast from the counts obtained in this study (large areas of apparently suitable habitat may be unoccupied), the small proportion of the area surveyed suggest that the numbers reported here may considerably underestimate the total population size of Peruvian Terns in Perú. A similar situation is found in Chile where 257-287 individuals were counted at eight localities clustered in the Peninsula of Mejillones and nearby areas (Guerra-Correa 2003).

\section{The importance of coastal wetlands}

Peruvian Terns were not found exclusively at inland desert plains as previously thought, but also in coastal wetlands (Table I). It is likely that the shallow waters of the estuaries offer optimal conditions for foraging. The Least Tern Sternula albifrons, a close relative of the Peruvian Tern, preferentially feeds at the entrances of wetland channels and coastal lagoons, where the availability of schools of juvenile fish is enhanced by strong current and tidal phases (Bertolero et al. 2005, Paiva et al. 2008). Nevertheless, the cost of using these areas for foraging and breeding is high. Wetlands of the Peruvian coast have high levels of human disturbance, pollution and water use for irrigation. It is not surprising that Peruvian Terns have abandoned the wetlands of Puerto Viejo and Mollendo (Zavalaga et al. 2008), and are currently threatened at San Pedro de Vice, Paraíso and Ite by recreational activities and urban development. Conversely, farther inland, colonies such as Pacasmayo, Pampa Lechuzas and Tres HermanasYanyarina have persisted over decades.

\section{Human-related threats and conservation actions}

With only four known breeding sites and ten non-breeding locations, which hold small numbers of nests and individuals, the conservation status of the Peruvian Tern in Perú is critical. The Peruvian Tern is categorized as 'Vulnerable' by the Ministry of Agriculture of Perú, but it should be uplisted to 'Endangered' following the IUCN Red List Criteria (Birdlife International 2008). In Perú, there are no management measurements or regulations for the conservation of Peruvian Terns because there is a lack of information on their distribution, numbers, and life history. Even worse, the majority of authorities and public are unaware that these terns nest on the coastal desert plains and beaches of Perú. The land used by Peruvian Terns in Perú is legally protected only at Pampa Lechuzas in the Paracas National Reserve and in the sanctuary of Mejía. The case of the Peruvian Tern is far from unique. Small terns which nest near the sea are threatened throughout the world by coastal development. In the United States, coastal populations of the Least Tern Sternula antillarum are under great pressure from development (e.g. Elliott et al. 2007). In Namibia, hatching success of the Damara Tern Sternula balaenarum was severely compromised by the use of breeding areas by fishermen and tourists. There, barriers protecting the nesting grounds doubled the number of chicks produced in the protected area (Braby et al. 2001).

Similarly, the number of encounters between Peruvian Terns and humans has increased as a result of sharp urban population growth (INEI 2008), and human expansion and settlement into previously pristine areas on the coast. The main threats include: (I) recreational activities 
(at San Pedro de Vice and Paraíso), (2) off-road driving by fishermen and tourists (at Pacasmayo, Paraíso, Tres Hermanas-Yanyarina and Pampa Lechuzas), (3) wetland pollution and water use for irrigation (at Paraíso and Mejía), (4) conversion of desert plains into agricultural land (at Punta Literas-Pativilca), (5) management of wetland water levels (at Ite), (6) presence of feral cats and dogs (at Isla Lobos de Tierra, Tres Hermanas-Yanyarina), and (7) oil exploration near tern areas (at San Pedro de Vice).

These adverse factors can be minimized by simultaneous protection of tern sites and education. A restriction on vehicles and an increase in vigilance on beaches should be enforced during the breeding season, for example by the construction of sand barriers (high bumps or wide deep channels). The access of vehicles to wetland beaches is naturally restricted by lagoons and marshes and the only access to the beaches are narrow entrances relatively easy to control. In wider nesting areas in the desert plains, well-demarcated trails and roads may reduce off-road driving. The posting of signboards may provide information to identify ecologically sensitive tern areas. Educational programmes in towns located close to the nesting areas describing the rarity of these terns and their susceptibility to human disturbance are necessary. Finally, the unprotected breeding sites of Pacasmayo, Tres Hermanas-Yanyarina and Paraíso should be declared legally protected to reduce the interactions with humans and to prevent habitat destruction due to urban and industrial development.

\section{Research priorities}

We suggest a list of research priorities that should be addressed in the following years. Most of these studies can only be accomplished with a coordinated effort among Ecuadorian, Peruvian and Chilean researchers and birders.

- A census of Peruvian Terns along the Peruvian and Chilean coast during the breeding season to determine latitudinal trends, hotspots for breeding, population size, habitat use and threats. Although a complete survey of $3,000 \mathrm{~km}$ of coast is unrealistic, a stratified random sampling technique along this desert strip would be appropriate. This census method has been applied in Damara Terns along the Namibia's desert (Simmons 1993, Simmons et al. 1998).

- Monthly counts at major nesting areas over several years to examine population trends.

- Collection of fresh eggshell remains and downy feathers from chicks to investigate the foraging ecology of Peruvian Terns during the breeding season throughout the analysis of stable isotopes of carbon and nitrogen.

- The downy feathers can be also used to examine patterns of genetic structure of the population using DNA-based techniques.

- Radio-tracking of adults during the breeding season to determine foraging ranges and habitat use. Tracking of adults after breeding is also important, but even the today's smallest GPS loggers or satellite transmitters are still too heavy for a 50-g bird.

- Banding programmes of adults and chicks to elucidate patterns of winter dispersion. Color bands must be more appropriate for sightings at distance.

- Studies of breeding biology with emphasis in the assessment of breeding success.

\section{Acknowledgements}

We thank A. García-Godos, G. Engblom, M. Ugarte-Lewis and F. Angulo-Pratolongo for sharing with us information of Peruvian Tern sightings. The fieldwork in San Pedro de Vice was made possible with the support and collaboration of C. Hwang, A. Arevalo-Zeta and A. BacayánAmaya. Surveys in 2008 were funded by American Bird Conservancy. The Regional Government of Lima gave financial support for the surveys at Paraíso during 2008. 


\section{References}

Bertolero, A., Oro, D., Martínez-Vilalta, A. and López, M. A. (2005) Selection of foraging habitats by Little Terns Sterna albifrons at the Ebro Delta (NE Spain). Rev. Catalana Ornitol. 21: 37-42.

Birdlife International (2008) Species factsheet: Sterna lorata. Downloaded from http:// www.birdlife.org on 11 August 2008.

Braby, R. J., Shapira, A. and Simmons, R. E. (2001) Successful conservation measures and new breeding records for Damara terns Sterna balaenarum in Namibia. Marine Ornithol. 29: 81-84.

Chávez, C. (2007) Las aves del santuario de conservación regional manglares San Pedro de Vice, Sechura, Perú. Cotinga 27: 32-37.

Coker, R. E. (1919) Habits and economic relations of the guano birds of Perú. Proc. U.S. Nat. Mus. 56: 449-511.

Devillers, P. and Terschuren, J. A. (1976) Some distributional records of migrant North American Charadriiformes in coastal South America (continental Argentina, Falkland, Tierra del Fuego, Chile, and Ecuador. Gerfaut 66: 107-125.

Elliot, M. L., Hurt, L., Sydeman, R. and William, J. (2007) Breeding biology and status of the California Least Tern Sterna antillarum browni at Alameda Point, San Francisco Bay, California. Waterbirds 30 : 317-325.

Galarza, N. (1968) Informe sobre los estudios ornitológicos realizados en el laboratorio de La Puntilla (Pisco) en Setiembre 1965/ 1966. Informe Especial Instituto del Mar del Perú (Callao) 31: 1-20.

González, C. (1990) Observaciones ornitológicas. Bol. Informativo Unión de Ornitólogos de Chile 9: 5 .

Goodall, J., Johnson, A. and Philippi, R. (1951) Las aves de Chile. Volume 2. Buenos Aires, Argentina: Platt Establecimientos Gráficos S. A.

Guerra-Correa, C. (2003) Nidificación del Gaviotín Chirrió, Sterna lorata en Bahía de Mejillones del Sur: Mitigación y manejo para la protección de las poblaciones locales. Chile: Corporación Nacional del Cobre de Chile, CODELCO FUREME. Informe 2002 Año 1.
Harrison, P. (1985) Seabirds, an identification guide. New York, U.S.: Houghton Mifflin Company.

INEI (2008) Resultados Censos de Población y Vivienda 2007: Anexo Estadístico. Instituto Nacional de Estadística e Informática. Downloaded from www.inei.gob.pe on 13 August 2008.

Hughes, R. A. (1970) Notes on the birds of the Mollendo district, southwest Perú. Ibis 112: 229-241.

Murphy, R. C. (1936) Oceanic birds of South America. Volume 2. New York, US: McMillan.

Paiva, V. H., Ramos, J. A., Martins, J., Almeida, A. and Carvalho, A. (2008) Foraging habitat selection by Little Terns Sternula albifrons in an estuarine lagoon system of southern Portugal. Ibis 150: 18-31.

Rottmann, J. and González, C. (I991) Gaviotín chico (Sterna lorata). Bol. Informativo Unión de Ornitólogos de Chile 11: 13.

Simmons, R. (1993) A census of the desertbreeding Damara Tern Sterna balaenarum in Namibia. Proc. VIII Pan-Afr. Orn. Congr: $395-398$.

Simmons, R. E., Cordes, I. and Braby, R. (1998) Latitudinal trends, population size and habitat preferences of the Damara Tern Sterna balaenarum on Namibia's desert coast. Ibis 140: 439-445.

Tello, A., Engblom, G., Merino, P. and Chalco, J. J. (2005) Sterna lorata, situación en la costa central del Perú. P. 117 in F. RivaMelofiro and A. More, eds. Libro de resúmenes VI Congreso Nacional de Ornitología Chiclayo, Perú. Chiclayo, Perú.

Valega, R. C. (2007) Avifauna of a relict mangrove forest in San Pedro, dpto. Piura, Perú. Cotinga 27: 42-47.

Vilina, Y. A. (1998) Breeding observations of the Peruvian tern in Chile. Colon. Waterbirds 21: 101-103.

Zavalaga, C. B., Frere, E. and Gandini, P. (2002) Status of the Red-legged Cormorant in Perú: What factors affect distribution and numbers? Waterbirds 25: 8-15.

Zavalaga, C. B., Bertolero, A. and Plenge, M. (2008) Nesting habitat and numbers of 
Peruvian Terns (Sternula lorata) at five breeding sites in the central-southern coast of Perú. Ornitología Neotropical 19: 587594 .
Zavalaga, C. B., Bertolero, A. and Plenge, M. (in press). The breeding biology of the Peruvian Tern (Sternula lorata) in Perú. Waterbirds 31: 550-560.

\section{CARLOS B. ZAVALAGA*}

Department of Biology and Marine Biology. University of North Carolina Wilmington. 601 South College Road, Wilmington, NC 28403-5915, U.S.A.

\section{JESSICA HARDESTY}

American Bird Conservancy, P. O. Box 249. 4249 Loudoun Ave, The Plains, VA 20198-0249. U.S.A.

\section{GINA P. MORI}

Calle Eduardo del Castillo 2543. Lima, Lima-1, Perú.

\section{CÉSAR CHÁVEZ-VILLAVICENCIO}

Instituto Internacional de Conservación y Manejo de Vida Silvestre (ICOMVIS). Universidad Nacional de Costa Rica. Apartado Postal 1350-30oo. Heredia, Costa Rica.

\section{ALEJANDRO TELLO}

Calle Carlos Pareja y Paz Soldán 140. Urb. Pando, San Miguel. Lima, Perú.

*Author for correspondence; e-mail: cbz3724@alum.uncw.edu

Received 15 May 2008; revision accepted 27 August 2008 